Gut, 1979, 20, 137-140

\title{
Serum bilirubin: a prognostic factor in primary biliary cirrhosis
}

\author{
J. M. SHAPIRO, H. SMITH, AND F. SCHAFFNER \\ From the Division of Liver Diseases of the Department of Medicine and The Department of \\ Bio-Statistics, Mount Sinai School of Medicine of The City University of New York, New York, USA
}

SUMMARY We followed up 55 patients with proven primary biliary cirrhosis for several years or until death. A graph of the level of serum bilirubin ve:sus time that was constructed for each patient shows an initial stable period of variable length in which the serum bilirubin level remained constant. This was followed by a period of rapid rise in serum bilirubin which culminated in the patient's death. Whenever two successive serum bilirubin values taken six months apart exceeded $34 \mu \mathrm{mol} / \mathrm{l}$ $(2.0 \mathrm{mg} / \mathrm{dl})$ the patient had entered a late phase of disease and lived an average of 49 months. Ninety-five per cent confidence limits on survival time were 32-74 months. If two successive six month bilirubin values exceeded $102 \mu \mathrm{mol} / 1(6.0 \mathrm{mg} / \mathrm{dl})$, calculated survival time was 25 months, and if two successive six month bilirubin values exceeded $170 \mu \mathrm{mol} / 1(10.0 \mathrm{mg} / \mathrm{dl})$, survival time was 17 months. Fifteen of the 41 living patients had two consecutive serum bilirubin levels greater than $34 \mu \mathrm{mol} / 1(2.0 \mathrm{mg} / \mathrm{dl})$. However, the slope of the rising bilirubin in the living patients is only 25 $\mu \mathrm{mol} / 1 / \mathrm{yr}(1.5 \mathrm{mg} / \mathrm{dl} / \mathrm{yr})$ compared with $42 \mu \mathrm{mol} / \mathrm{l} / \mathrm{yr}(2.5 \mathrm{mg} / \mathrm{dl} / \mathrm{yr})$ in the dead patients. This means that patients with this disease now may be living considerably longer.

Primary biliary cirrhosis is a chronic progressive liver disease that ultimately kills its victims. Its pathogenesis is unknown (although antigen- antibody complexes are thought to play a role) (Thomas et al., 1977) and various methods of treatment have failed to show a definite lengthening of lifespan. The length of life after diagnosis, however, is highly variable. Patients may die rapidly within one year or remain asymptomatic for many years.

Although pathologically the disease is divided into four stages (Rubin et al., 1965), these cannot be used to predict prognosis. Also, no symptom, sign, or laboratory test has been correlated with length of life after diagnosis. As a result of our experience with 55 recent cases of primary biliary cirrhosis, we indicate the potential use of serum bilirubin as a predictor of prognosis.

\section{Methods}

Fifty-five patients with proven primary biliary cirrhosis were used as the sample, 48 female, seven male. At the time of diagnosis the patients' ages

Received for publication 8 September 1978 ranged from 26 to 69 years with the median age being 49 years; the majority $(69 \%)$ were in their $40 \mathrm{~s}$ or $50 \mathrm{~s}$. The patients were followed up at three to six month intervals for an average duration of 4.6 years. Fourteen of the patients were followed up until death, which averaged 6.6 years from diagnosis.

All patients had the following laboratory evaluations: total serum bilirubin, alkaline phosphatase, alanine aminotransferase, aspartate aminotransferase, cholesterol, gamma-glutamyl transpeptidase, immunoelectrophoresis, and mitochondrial antibody. All patients had unobstructed biliary ducts demonstrated by intravenous cholangiography, endoscopicretrograde cholangiopancreatography, or operative cholangiography. No patient had been treated with any medication which would alter the results of any of the above tests.

Using a decision rule for indicating the beginning of a rapid rise in bilirubin associated with death, the geometric mean survival time was determined under the assumption of a log-normal survival time distribution (Aitchinson and Brown, 1957). Ninety-five percent confidence limits on the true mean survival time for these cohorts were obtained. 
Results

\section{PRESENTATION}

Most patients $(67 \%)$ presented with pruritus or fatigue or both. Nine patients $(16 \%)$ had no symptoms and were found because of abnormalities in routine blood chemistry tests performed for other reasons.

Other modes of presentation included jaundice (six patients), arthritis (one), Raynaud's phenomenon (one), and variceal haemorrhage (one). Prognosis did not correlate with the mode of presentation.

\section{PHYSICAL EXAMINATION}

Liver size, spleen size, or the initial presence of jaundice did not correlate with length of life after diagnosis.

\section{OTHER LABORATORY TEST RESULTS}

Eighty percent of the patients $(44 / 55)$ had positive immunofluorescence tests for mitochondrial antibody. All patients initially had raised activities of alkaline phosphatase and gamma glutamyl-transpeptidase in serum; $87 \%(48 / 55)$ had initially raised aminotransferase activity; $54 \%(30 / 55)$ initially had raised serum cholesterol concentration. None of these abnormalities correlated with prognosis.

The blood tests were repeated each time the patient was seen (except mitochondrial antibody) and changes could not be correlated with length of life from onset of symptoms or diagnosis.

\section{SERUM BILIRUBIN}

At presentation $69 \%(38 / 55)$ had initial serum bilirubin concentrations less than or equal to 34 $\mu \mathrm{mol} / 1(2.0 \mathrm{mg} / \mathrm{dl})$. Twenty-two per cent $(12 / 55)$ presented with values between $35 \mu \mathrm{mol} / 1 \quad(2 \cdot 1$ $\mathrm{mg} / \mathrm{dl})$ and $68 \mu \mathrm{mol} / 1(4.0 \mathrm{mg} / \mathrm{dl})$. The remaining five patients $(9 \%)$ had initial serum bilirubin concentrations greater than or equal to $69 \mu \mathrm{mol} / \mathrm{l}$ $(4 \cdot 1 \mathrm{mg} / \mathrm{dl})$.

Fourteen patients $(25 \%)$ were followed up until death, which averaged 6.6 years. Three had initial serum bilirubin concentrations less than $34 \mu \mathrm{mol} / 1$ $(2.0 \mathrm{mg} / \mathrm{dl})$ (average time until death was nine years), seven had values between $35 \mu \mathrm{mol} / 1(2 \cdot 1$ $\mathrm{mg} / \mathrm{dl})$ and $68 \mu \mathrm{mol} / 1(4.0 \mathrm{mg} / \mathrm{dl})$ (average time until death was 6.7 years), and four had initial values greater than $69 \mu \mathrm{mol} / \mathrm{l}(4 \cdot 1 \mathrm{mg} / \mathrm{dl})$ (average time until death was 5.3 years). There was a trend favouring longevity when initial serum bilirubin concentrations were under $34 \mu \mathrm{mol} / 1(2.0 \mathrm{mg} / \mathrm{dl})$ but this did not reach significant levels $(P>0 \cdot 1)$.

By plotting the values of the repeated serum bilirubin determinations versus time; a bilirubin graph was constructed for each patient. These plots all had an initial stable period of variable length in which the serum bilirubin remained fairly constant (usually below $34 \mu \mathrm{mol} / 1(2.0 \mathrm{mg} / \mathrm{dl})$. In the living patients, this time period averaged three years. After this came a period of rapid rise, in which the serum bilirubin increased dramatically. It was after this period of rapid rise that the patients invariably died. Except for one patient who exsanguinated from a massive upper gastrointestinal haemorrhage, no patient died with a serum bilirubin below 204 $\mu \mathrm{mol} / \mathrm{l}(12 \mathrm{mgd} / \mathrm{l})$.

The important part in each patient's curve was the change from the flat stable portion to the rapidly rising portion. Analysis of the data indicated that the earliest determinant of this change was when two successive serum bilirubin values, taken at least six months apart, exceeded $34 \mu \mathrm{mol} / 1(2.0 \mathrm{mg} / \mathrm{dl})$.

Using the occurrence of two successive serum bilirubin values greater than $34 \mu \mathrm{mol} / \mathrm{l}(2.0 \mathrm{mg} / \mathrm{dl})$ as an indicator of impending death, the survival time distribution from this point on was assumed to be log-normal. Analysis showed the geometric mean survival time to be 49 months. A $95 \%$ confidence interval for the true mean survival time was calculated to be 32-74 months (Table).

The above calculation was used for all patients in the sample. However, we observed that if the first two serum bilirubin values were both much above $34 \mu \mathrm{mol} / 1(2.0 \mathrm{mg} / \mathrm{dl})$, the patient was already on the rapidly rising part of the curve and survival was shorter. A mean survival time was calculated for two successive serum bilirubin values greater than 102 $\mu \mathrm{mol} / 1(6.0 \mathrm{mg} / \mathrm{dl})$. This equalled 25 months, with a $95 \%$ confidence interval survival time of 19-32 months. When patients had two successive bilirubin values greater than $170 \mu \mathrm{mol} / \mathrm{l}(10.0 \mathrm{mg} / \mathrm{dl})$ estimated survival time was 17 months with a $95 \%$ confidence interval of 13-22 months (Table).

Table Predicted geometric mean survival times and $95 \%$ confidence limit for patients with primary biliary cirrhosis using successive values for serum bilirubin

\begin{tabular}{lll}
\hline $\begin{array}{l}\text { Two successive serum } \\
\text { bilirubins } 6 \text { m apart }\end{array}$ & $\begin{array}{l}\text { Geometric mean } \\
\text { survival time } \\
\text { (months) }\end{array}$ & $\begin{array}{l}95 \% \text { confidence } \\
\text { limits on survival } \\
\text { time (months) }\end{array}$ \\
\hline$>34 \mu \mathrm{mol} / 1(2.0 \mathrm{mg} / \mathrm{dl})$ & 49 & $32-74$ \\
$>102 \mu \mathrm{mol} / 1(6.0 \mathrm{mg} / \mathrm{dl})$ & 25 & $19-32$ \\
$>170 \mu \mathrm{mol} / 1(10 \mathrm{mg} / \mathrm{dl})$ & 17 & $13-22$ \\
\hline
\end{tabular}

The patients' individual graphs were combined into two cumulative graphs (Figs 1 and 2). Figure 1 shows the data for the living patients. As expected, they had an initial stable period (averaging 36 


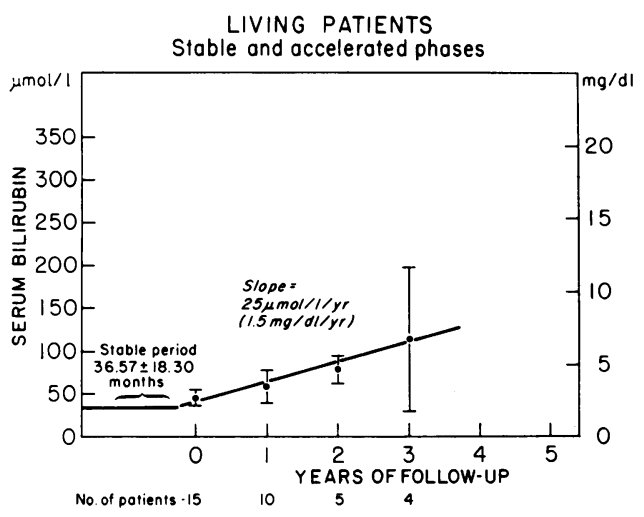

Fig. 1 Serum bilirubin versus time for the 15 living patients who have had two consecutive serum bilirubin values greater than $34 \mu \mathrm{mol} / \mathrm{l}(2.0 \mathrm{mg} / \mathrm{dl})$. The initial horizontal line shows the stable period before this change in serum bilirubin (averaging three years). The diagonal line denotes the linear rate of rise over time after the change in serum bilirubin. Results for each value are expressed $\pm S E M$.

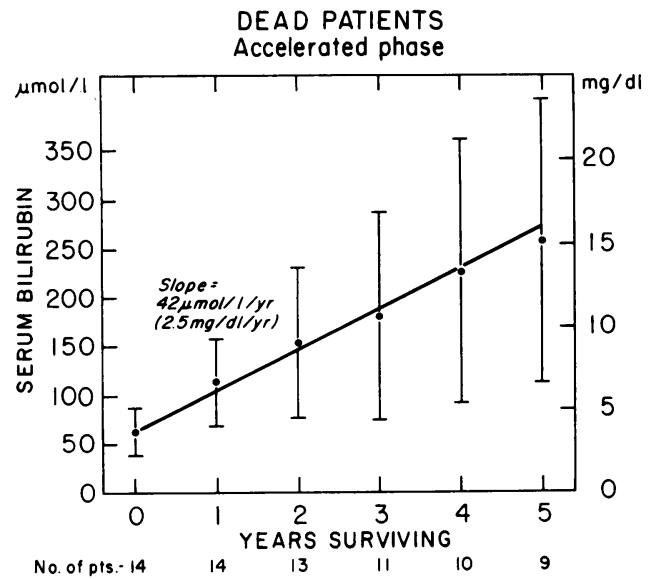

Fig. 2 Serum bilirubin versus time in the 14 patients followed up until death. The line shows the approximate linear rate of rise of serum bilirubin after two consecutive previous values were both greater than $34 \mu \mathrm{mol} / \mathrm{l}(2.0 \mathrm{mg} / \mathrm{dl})$. Please note the slope difference between Fig. 1 and 2. Results for each value are expressed $\pm S E M$.

months) in which no two successive serum bilirubins were greater than two. Fifteen of these 41 patients then enterep the accelerated phase, with serum bilirubin concentration rising steadily over time. The average rise for these patients was 24 $\mu \mathrm{mol} / 1 / \mathrm{yr}(1.5 \mathrm{mg} / \mathrm{dl} / \mathrm{yr})$. Figure 2 shows the data for the dead patients. Most of these patients presented already jaundiced, so no stable period is shown, only the phase of rising serum bilirubin, which averaged $42 \mu \mathrm{mol} / 1 / \mathrm{yr}(2.5 \mathrm{mg} / \mathrm{dl} / \mathrm{yr})$. The graphs differ, with the slope of the curve for the deceased patients greater than the slope for the live ones. It now is taking the serum bilirubin longer to rise from $34 \mu \mathrm{mol} / 1(2.0 \mathrm{mg} / \mathrm{dl})$ to $170 \mu \mathrm{mol} / 1$ (10 $\mathrm{mg} / \mathrm{dl}$ ) and thus living patients will live longer.

\section{Discussion}

Death in primary biliary cirrhosis usually results from hepatic insufficiency, portal hypertension with resultant variceal haemorrhage, or sepsis. The survival time from diagnosis until death is highly variable. To define an approximate lifespan for these patients would be important.

Of the 55 patients with proven primary biliary cirrhosis whom we have been following up for long periods of time, 14 have died with an average time from diagnosis of 6.6 years. The behaviour in each patient of serum bilirubin versus time is surprisingly uniform. The usually normal initial serum bilirubin values remain constant for several years. This is followed by a phase of rapid increase in serum bilirubin which invariably culminates in the patient's death; patients rarely die of their disease before this rapid rise. The change in slope of the bilirubin curve is marked by two successive bilirubin values exceeding $34 \mu \mathrm{mol} / \mathrm{l}(2 \cdot 0 \mathrm{mg} / \mathrm{dl})$.

We believe that this change in serum bilirubin that occurs while the patient is being followed up is an indication of the length of time that the patient will survive. Using these changes in serum bilirubin we have defined a prediction which states that when two successive serum bilirubin values taken six months apart both exceed $34 \mu \mathrm{mol} / \mathrm{l}(2.0 \mathrm{mg} / \mathrm{dl})$, the patient has entered a late phase of the disease. Once this has happened the patients lived an average of four years with a range of three to six years.

When two successive serum bilirubin values excedeed $102 \mu \mathrm{mol} / 1(6.0 \mathrm{mg} / \mathrm{dl})$ expected life was shortened to 1.5 to 2.5 years with an average of two years. With two successive bilirubin values greater than $170 \mu \mathrm{mol} / \mathrm{l}(10 \mathrm{mg} / \mathrm{dl})$, lifespan for these patients was further shortened, averaging less than 1.5 years.

One possible explanation of why the change in serum bilirubin correlates with survival relates to copper. Because of the damage to the bile ducts the liver is unable to excrete the normal amount of bile. Copper is absorbed from the gastrointestinal tract and $80 \%$ of it is excreted in the bile (Cartwright and Wintrobe, 1964). The normal route of excretion becomes blocked in primary biliary cirrhosis and the amount of copper increases in the hepatic parenchyma (Hunt et al., 1963). Copper is hepatotoxic in 
both man (Chuttani et al., 1965; Sternlieb, 1972) and experimental animals (Todd et al., 1962). The accumulation of copper in the liver may be responsible for the rapid final deterioration of patients with primary biliary cirrhosis. The early promising results using D-penicillamine, a copper chelating agent, in treating patients with primary biliary cirrhosis support this hypothesis (Deering et al., 1977; Jain et al., 1977). This drug decreases hepatic copper levels (Deering et al., 1977) but whether it will prolong life is not established.

The prognostic sign we have proposed needs to be verified by following up more patients with primary biliary cirrhosis from the very early stages of the disease to death. The application of this rule to 41 living patients presently being followed up indicates that $39 \%$ (15 patients) are in imminent danger. The average time between diagnosis and the change in serum bilirubin for these patients was three years. This differs from that in the dead patients whose initial serum bilirubin averaged $51 \mu \mathrm{mol} / 1(3 \mathrm{mg} / \mathrm{dl})$. The combined plots of both groups are seen in Figs 1 and 2. The other difference is that the slope of the bilirubin curve rises less steeply in the living patients than in the dead ones-25 $\mu \mathrm{mol} / \mathrm{l} / \mathrm{yr}$ $(1.5 \mathrm{mg} / \mathrm{dl} / \mathrm{yr})$ as compared with $42 \mu \mathrm{mol} / \mathrm{l} / \mathrm{yr}$ $(2.5 \mathrm{mg} / \mathrm{dl} / \mathrm{yr})$. This observation means that survival is greatly increasing even after the late or jaundiced phase of the disease has begun, possibly because supportive therapy has improved. The extrapolated duration of the accelerated phase is $5 \frac{1}{2}$ years until the serum bilirubin reaches $170 \mu \mathrm{mol} / 1(10 \mathrm{mg} / \mathrm{dl})$ and therefore our expected survival for the living patients just entering this phase is approximately seven years.

\section{References}

Aitchinson, J., and Brown, J. A. C. (1957). The Lognormal Distribution. Cambridge University Press: Cambridge (Cambridge University, Department of Applied Economics, Monographs, 5).

Cartwright, G. E., and Wintrobe, M. M. (1964). Copper metabolism in normal subjects. American Journal of Clinical Nutrition, 14, 224-232.

Chuttani, H. K., Gupta, P. S., Gulati, S., and Gupta, D. N. (1965). Acute copper sulfate poisoning. American Journal of Medicine, 39, 849-854.

Deering, T. B., Dickson, E. R., Fleming, C. R., Geall, M. G., McCall, J. T., and Baggenstoss, A. H. (1977). Effect of D-penicillamine on copper retention in patients with primary biliary cirrhosis. Gastroenterology, 72, 1208-1212.

Hunt, A. H., Parr, R. M., Taylor, D. M., and Trott, N. G. (1963). Relation between cirrhosis and trace metal content of liver, with special reference to primary biliary cirrhosis and copper. British Medical Journal, 2, 1498-1501.

Jain, S., Scheuer, P. J., Samourian, S., McGee, J. O'D., and Sherlock, S. (1977) A controlled trial of D-penicillamine therapy in primary biliary cirrhosis. Lancet, 1, 831-834.

Rubin, E., Schaffner, F., and Popper, H. (1965). Primary biliary cirrhosis: Chronic non-supurative destructive cholangitis. American Journal of Pathology, 46, 387-407.

Sternlieb, I. (1972). Evolution of the hepatic lesion in Wilson's disease (hepatolenticular degeneration). In Progress in Liver Diseases, vol. 4, pp. 511-525. Edited by H. Popper and F. Schaffner. Grune and Stratton: New York.

Thomas, H. C., Potter, B. J., and Sherlock, S. (1977). Is primary biliary cirrhosis an immune complex disease? Lancet, 2, 1261-1263.

Todd, J. R., Gracey, J. F., and Thompson, R. H. (1962). Studies on chronic copper poisoning I. Toxicity of copper sulphate and copper acetate in sheep. British Veterinary Journal, 118, 482-491. 